\title{
Uptake of Cholesterol-rich Remnant Lipoproteins by Human Monocyte-derived Macrophages Is Mediated by Low Density Lipoprotein Receptors
}

\author{
Catherine Koo, " Mary Ellen Wernette-Hammond," Zarah Garcia," Mary J. Malloy,, Ricardo Uauy," Cara East," \\ David W. Bilheimer," Robert W. Mahley," and Thomas L. Innerarity* \\ * Gladstone Foundation Laboratories for Cardiovascular Disease, Cardiovascular Research Institute, Departments of Pathology \\ and Medicine, ${ }^{\ddagger}$ Departments of Medicine and Pediatrics, University of California, San Francisco, California 94140-0608; \\ 'Department of Pediatrics and Center for Human Nutrition, "Department of Internal Medicine, \\ University of Texas Health Science Center, Dallas, Texas 75235
}

\begin{abstract}
The uptake and degradation of cholesterol-rich remnant lipoproteins, referred to as $\beta$-VLDL, are shown in the present study to be mediated by LDL receptors (apoB,E(LDL) receptors), not by unique $\beta$-VLDL receptors. Human blood monocytes cultured for 5-7 d bound apoB- and/or apoE-containing lipoproteins from different species with affinities equivalent to those demonstrated for the receptors on cultured human fibroblasts. Low density lipoproteins competed effectively and completely with ${ }^{125} \mathrm{I}-\boldsymbol{\beta}$-VLDL for binding to and degradation by monocyte-derived macrophages. Specific polyclonal antibodies to bovine apoB,E(LDL) receptors abolished both $L D L$ and $\beta$-VLDL uptake by normal human monocyte-macrophages. Immunoblots of monocyte-macrophage extracts with these antibodies revealed a single protein in human macrophages with an apparent molecular weight identical to that of the apoB,E(LDL) receptor found on human fibroblasts. Like receptors on cultured human fibroblasts, the apoB,E(LDL) receptors on monocyte-macrophages responsible for ${ }^{125} \mathrm{I}-\boldsymbol{\beta}$ VLDL and ${ }^{125}$ I-LDL uptake were efficiently down regulated by preincubation of the cells with $\beta$-VLDL or LDL. Finally, monocyte-macrophages from seven homozygous familial hypercholesterolemia subjects were unable to metabolize $\beta$ VLDL or LDL, but demonstrated normal uptake of acetoacetylated LDL. The classic apoB,E(LDL) receptors on human monocyte-macrophages thus mediate the uptake of $\beta$-VLDL by these cells.
\end{abstract}

\section{Introduction}

The development of diet-induced atherosclerosis is associated with the accumulation of cholesterol-enriched remnant lipoproteins of intestinal and hepatic origin; these are referred to as $\beta$-VLDL (for review, see references 1-3). Experimental animals fed a high-cholesterol diet accumulate large quantities of these chylomicron and VLDL remnants in their plasma. Coincidental with the appearance of $\beta$-VLDL in their plasma is the

Address reprint requests to Dr. Innerarity, Gladstone Foundation Laboratories for Cardiovascular Disease, P. O. Box 40608, San Francisco, CA 94140-0608. Dr. Koo is currently affiliated with the Department of Medicine, University of California, San Francisco, CA 94143.

Received for publication 30 June 1987 and in revised form 7 October 1987.

J. Clin. Invest.

(c) The American Society for Clinical Investigation, Inc.

0021-9738/88/05/1332/09 \$2.00

Volume 81, May 1988, 1332-1340 deposition of cholesteryl esters in the macrophages in a variety of tissues $(3,4)$. The sequestration of cholesteryl esters by the macrophages appears to result from the specific uptake of these lipoproteins through a receptor-mediated mechanism (5, 6). The most common mechanism of extrahepatic cellular uptake of lipoproteins is through the well-described apolipoprotein (apo) B,E(LDL) receptor pathway (7). However, results from initial studies using mouse peritoneal macrophages as a model for tissue macrophages showed that these cells bind and internalize only small amounts of LDL, whereas $\beta$-VLDL are actively taken up and degraded $(5,6)$. Furthermore, LDL were not effective competitors of $\beta$-VLDL degradation by mouse peritoneal macrophages $(5,6)$.

On the basis of these observations, it was proposed that a specific population of receptors on mouse peritoneal macrophages, different from the classic apoB,E(LDL) receptor, mediated the uptake of $\beta$-VLDL and the development of these cells into foam cells $(5,6)$. Recent studies, however, have shown that the uptake of $\beta$-VLDL by mouse peritoneal macrophages is mediated not by a specific $\beta$-VLDL receptor, but by an apoB,E(LDL) receptor $(8,9)$. One property differentiating the mouse apoB,E(LDL) receptor on macrophages from the classic apoB, $E(L D L)$ receptor is its binding affinity for $L D L$; the LDL bound to mouse peritoneal macrophages with a 10fold lower affinity than to cultured human fibroblasts (8). This unexpectedly low affinity for LDL, compounded by the smaller number of apoB,E(LDL) receptors on mouse peritoneal macrophages (8), resulted in the modest uptake of LDL by mouse peritoneal macrophages. Furthermore, recent studies by Tabas et al. (10) indicated that mouse peritoneal macrophages displayed defective acyl CoA:cholesterol acyltransferase (ACAT) ${ }^{1}$ activation by LDL, even under conditions where receptor-mediated LDL uptake and degradation had taken place. Such inability to esterify LDL-derived cholesterol would exaggerate the effect of the smaller number of apoB,E(LDL) receptors, making it appear that there are even fewer apoB,E(LDL) receptors on these cells.

In addition, whereas the classic apoB,E(LDL) receptors on human fibroblasts are exquisitely sensitive to down regulation by cholesterol derived from LDL and $\beta-V L D L$, the apoB,E(LDL) receptors on mouse peritoneal macrophages are poorly down regulated (8). Because of the insensitive regulation of receptor levels in these cells, high levels of intracellular cholesteryl esters accumulate when the cells are incubated with $\beta$-VLDL, converting the macrophages into foam cells $(5,6)$.

1. Abbreviations used in this paper: AcAc LDL, acetoacetylated LDL; ACAT, acyl CoA:cholesterol acyltransferase; FH, familial hypercholesterolemia; LPDS, lipoprotein-deficient serum. 
Although mouse peritoneal macrophages internalize $\beta$ VLDL via apoB,E(LDL) receptors, other evidence suggested that human monocyte-derived macrophages may express an additional receptor that binds $\beta$-VLDL but not LDL (11). To determine the contribution of the apoB,E(LDL) receptor to $\beta$-VLDL uptake, Van Lenten et al. (11) studied the uptake of $\beta$-VLDL by monocytes derived from an individual homozygous for familial hypercholesterolemia (FH). These investigators found that while LDL degradation was vastly impaired as a result of the genetic deficiency of apoB,E(LDL) receptor expression, degradation of rabbit $\beta$-VLDL by these cells approached normal levels.

In the present study, we examined in detail the receptors responsible for $\beta$-VLDL uptake by human monocyte-derived macrophages. Our results demonstrate that $\beta$-VLDL enter the cells through an apoB,E(LDL) receptor that is apparently identical to the classic human fibroblast apoB,E(LDL) receptor in binding characteristics, sensitivity to regulation by cholesterol, and apparent molecular weight.

\section{Methods}

Materials. ${ }^{125} \mathrm{I}$-labeled Bolton-Hunter reagent, $\mathrm{Na}\left[{ }^{125} \mathrm{I}\right]$ iodine, ${ }^{125} \mathrm{I}-\mathrm{la}$ beled donkey anti-rabbit IgG antibody, and $\left[1-{ }^{14} \mathrm{C}\right]$ oleic acid were obtained from Amersham/Searle (Arlington Heights, IL). Fetal calf serum was purchased from HyClone (Logan, UT) and was heat inactivated $\left(56^{\circ} \mathrm{C}\right.$ for $30 \mathrm{~min}$ ) before use. DME (Gibco, Grand Island, NY), leupeptin (Vega Biotechnologies, Tucson, AZ), Trasylol (FBA Pharmaceuticals, New York, NY), phenylmethylsulfonyl fluoride (PMSF, Calbiochem, San Diego, CA), Triton X-100, turkey trypsin inhibitor, and soybean trypsin inhibitor (Sigma Chemical Co., St. Louis, MO) were obtained from the indicated suppliers.

Cell cultures. Blood was obtained from 20 healthy volunteers, 7 patients with homozygous familial hypercholesterolemia, and 1 patient with the heterozygous form of FH. Acid citrated dextrose was used as an anticoagulant. Mononuclear cells were isolated by FicollHypaque density centrifugation according to the method of Bøyum (12). The mononuclear cells were gently aspirated from the interface and washed three times. The cells were then resuspended in DME and transferred by aliquot into $22-$ or $35-\mathrm{mm}$ plastic tissue culture wells. After incubation at $37^{\circ} \mathrm{C}$ for $45-60 \mathrm{~min}$, the wells were washed three times with DME to remove nonadherent cells. The adherent monocytes were either used immediately for experiments or were cultured an additional 5-7 d to produce monocyte-derived macrophages. The culture medium consisted of DME with human serum (20\%), penicillin $(100 \mathrm{U} / \mathrm{ml})$, and streptomycin $(100 \mu \mathrm{g} / \mathrm{ml})$ and was replaced every other day.

Monolayers of normal human fibroblasts were cultured as described (13). Fibroblasts were seeded $5 \mathrm{~d}$ before each experiment and grown in DME containing $10 \%$ fetal calf serum.

Preparation of lipoproteins. Human LDL $(d=1.02-1.05 \mathrm{~g} / \mathrm{ml})$ were prepared by sequential ultracentrifugation of plasma from normal, fasted volunteers (13). Diketene modification of human LDL to yield acetoacetylated LDL (AcAc LDL) was performed as described by Weisgraber et al. (14). The $\beta$-VLDL and apoE $\mathrm{HDL}_{c}$ (cholesterol-induced plasma high density lipoproteins in which apoE is the sole protein constituent) were derived from dogs made hyperlipidemic (plasma cholesterol $>700 \mathrm{mg} / \mathrm{dl}$ ) by a semisynthetic diet containing coconut oil and cholesterol (15). The $\beta$-VLDL were isolated from the $d$ $<1.006 \mathrm{~g} / \mathrm{ml}$ fraction of plasma by Pevikon block electrophoresis as described (15). The $d=1.006-1.02 \mathrm{~g} / \mathrm{ml}$ fraction of the hyperlipidemic canine plasma was also subjected to Pevikon block electrophoresis to yield apoE $\mathrm{HDL}_{\mathrm{c}}$. Human $\beta$-VLDL were isolated as above from the plasma of an atypical type III hyperlipoproteinemic subject after an overnight fast (16). Rabbit $\beta$-VLDL were isolated as the $d<1.006 \mathrm{~g} /$ $\mathrm{ml}$ fraction from hyperlipidemic rabbit plasma. All lipoproteins were dialyzed against $0.15 \mathrm{M} \mathrm{NaCl} / 0.01 \%$ EDTA (pH 7.2) before use. Lipoprotein-deficient human serum (LPDS, $d>1.215 \mathrm{~g} / \mathrm{ml}$ ) was prepared by ultracentrifugation of normal human plasma followed by a 24-h dialysis against $0.15 \mathrm{M} \mathrm{NaCl} / 0.01 \%$ EDTA (pH 7.2) and a 48-h dialysis against PBS (pH 7.2).

The cholesterol concentrations of the various lipoproteins were assayed by the enzymatic spectrophotometric assay from Bio-Dynamics (Boehringer Mannheim Corp., Indianapolis, IN), and protein concentrations were determined by the method of Lowry et al. (17). Iodinated lipoproteins ( ${ }^{125} \mathrm{I}-\mathrm{LDL}$ and ${ }^{125} \mathrm{I}-\beta$-VLDL) were prepared by the iodine monochloride method (18) and had specific activities of between 200 and $400 \mathrm{cpm} / \mathrm{ng}$ of protein for LDL and 400 and 900 $\mathrm{cpm} / \mathrm{ng}$ of protein for $\beta$-VLDL. The Bolton-Hunter procedure was followed for the iodination of apoE $\mathrm{HDL}_{\mathrm{c}}$ and yielded specific activities of between 400 and 1,000 cpm/ng of protein (19).

Preparation of antibodies. Antibodies raised against the purified bovine apoB,E(LDL) receptor in New Zealand White rabbits were prepared by Dr. David Hui of the Gladstone Foundation Laboratories. The IgG was isolated by protein A-Sepharose affinity chromatography (20) and dialyzed against phosphate-buffered saline before use. Protein concentrations were determined by the method of Lowry et al. (17). Western blot analysis showed that the IgG preparations used in the present studies specifically recognized only apoB,E(LDL) receptors from extracts of human fibroblasts or bovine adrenal glands. In addition, this preparation of apoB,E(LDL) receptor antibodies blocked ${ }^{125} \mathrm{I}-\mathrm{LDL}$ binding to both human fibroblasts and canine liver membranes.

Lipoprotein binding assays. Binding assays were performed in 22or $35-\mathrm{mm}$ wells containing $1-2 \times 10^{6}$ monocytes, monocyte-derived macrophages, or confluent human fibroblasts. Unless otherwise stated, $2 \mathrm{~d}$ before assay, the cells were cultured in 10\% LPDS instead of fetal calf serum or normal human serum to induce maximal apoB,E(LDL) receptor expression. Cell-surface binding assays were performed at $4^{\circ} \mathrm{C}$ for $4 \mathrm{~h}$ as described (21). Nonspecific binding was defined as the amount of radiolabeled lipoprotein bound in the presence of a 100-fold excess of unlabeled ligand. The data were analyzed according to the method of Scatchard (22) to determine equilibrium dissociation constants $\left(K_{d}\right)$. In competition experiments, a constant amount of ${ }^{125} \mathrm{I}-\beta$ VLDL was present and the concentrations of the unlabeled competing ligands were varied. In experiments in which anti-apoB,E(LDL) receptor IgG was used, preimmune IgG was used as a control.

Measurement of cholesterol esterification. Lipoproteins were added to the cells along with $0.2 \mathrm{mM}\left[{ }^{14} \mathrm{C}\right]$ oleate/albumin and incubated at $37^{\circ} \mathrm{C}$ for $16-18 \mathrm{~h}(23,24)$. Lipids were extracted and cholesteryl esters were isolated by thin-layer chromatography. The amount of cholesteryl $\left[{ }^{14} \mathrm{C}\right]$ oleate was determined by liquid scintillation counting with $\left[{ }^{3} \mathrm{H}\right]$ cholesteryl oleate added as an internal standard (23). The lipoprotein-induced $\left[{ }^{14} \mathrm{C}\right]$ oleate incorporation was defined as the difference between the amount of $\left[{ }^{14} \mathrm{C}\right]$ oleate incorporated in the presence and absence of added lipoproteins. The amount of $\left[{ }^{14} \mathrm{C}\right]$ oleate incorporation in the absence of lipoproteins was usually less than $1 \mathrm{nmol} / \mathrm{mg}$ of cell protein.

Assay for lipoprotein degradation. Iodinated lipoproteins were added to the cell cultures in DME and were incubated at $37^{\circ} \mathrm{C}$ for 12-16 h. The extent of proteolytic degradation was determined by measuring the amount of ${ }^{125}$ I-labeled trichloroacetic acid-soluble material ( ${ }^{125}$ I-monotyrosine) $(24,25)$. Nonspecific degradation was defined as the amount of degradation observed in the presence of a 100-fold excess of unlabeled lipoprotein.

Western blots. Immunoblots of cell membrane proteins were performed as described (26). Briefly, Triton X-100 extracts of human monocyte-macrophages or fibroblasts were electrophoresed in $7.5 \%$ polyacrylamide-SDS gels under nonreducing conditions and were obtained by the method of Beisiegel et al. (27) in the presence of $0.5 \mathrm{mM}$ PMSF, $0.5 \mathrm{mg}$ of leupeptin/ml, 10,000 KIU of Trasylol, and turkey trypsin inhibitor and soybean trypsin inhibitor $(15 \mu \mathrm{g} / \mathrm{ml})$.

The proteins were transferred electrophoretically to nitrocellulose paper as described (28). Immunoblotting was performed using $50 \mu \mathrm{g}$ of 
apoB,E(LDL) receptor antibody $/ \mathrm{ml}$, and bound antibody was detected by incubation of the blot with ${ }^{125}$ I-labeled donkey anti-rabbit IgG (1-2 $\times 10^{6} \mathrm{cpm} / \mathrm{ml}$ ). Autoradiographs were obtained by exposing the dried blots to Kodak XS-5 film and Cronex enhancing screens.

\section{Results}

Lipoprotein binding characteristics of human monocyte-derived macrophages. The binding of several ${ }^{125} \mathrm{I}$-labeled lipoproteins to the surface of human monocyte-derived macrophages was measured at $4^{\circ} \mathrm{C}$. The binding of human ${ }^{125} \mathrm{I}-\mathrm{LDL}$, canine ${ }^{125} \mathrm{I}$-apoE $\mathrm{HDL}_{\mathrm{c}}$, and canine ${ }^{125} \mathrm{I}-\beta$-VLDL to cultured monocyte-macrophages was both saturable and concentration dependent (Fig. 1). Analyses of the data according to the method of Scatchard $(22,23)$ demonstrated that the human monocyte-macrophages bound ${ }^{125} \mathrm{I}-\mathrm{LDL}$ with a $K_{\mathrm{d}}$ $=1.65 \pm 0.07 \mu \mathrm{g} / \mathrm{ml}(n=3 ; \pm \mathrm{SD})$ and ${ }^{125} \mathrm{I}-\mathrm{apoE} \mathrm{HDL}_{\mathrm{c}}$ with a $K_{\mathrm{d}}=0.04 \mu \mathrm{g} / \mathrm{ml}(n=2)$. At receptor saturation, the ratio of $\mathrm{LDL}$ to apoE $\mathrm{HDL}_{c}$ bound to the cells was $4.8: 1$, which is similar to the ratio of 3.6:1 for the binding of these lipoproteins to the classic apoB,E(LDL) receptors on cultured human fibroblasts (29). The human monocyte-macrophages bound $\beta$ VLDL with a $K_{\mathrm{d}}=0.12 \pm 0.07 \mu \mathrm{g} / \mathrm{ml}(n=4$; $\pm \mathrm{SD})$, which is also similar to that of human fibroblasts for this class of lipoproteins.

Specificity of the lipoprotein receptor for $\beta-V L D L$. Equilibrium binding experiments indicated that human monocytemacrophages displayed receptors that bound all three classes of lipoproteins tested. To determine whether separate populations of receptors existed for LDL and $\beta$-VLDL, the specificity of $\beta$-VLDL binding was examined by assessing the ability of unlabeled human LDL to compete with canine ${ }^{125} \mathrm{I}-\beta$-VLDL for binding and degradation by human monocytes and monocyte-macrophages. Both unlabeled $\beta$-VLDL and LDL were

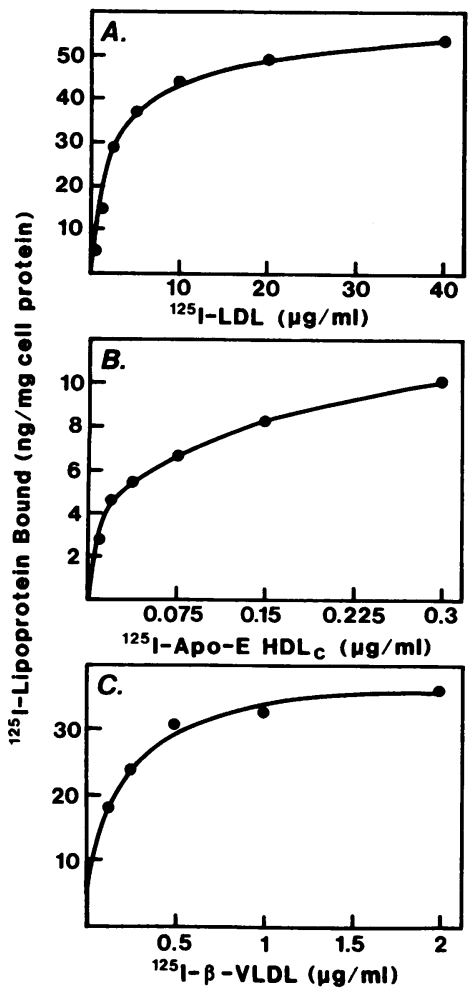

Figure 1. Concentrationdependent binding of ${ }^{125} \mathrm{I}$ labeled lipoproteins to human monocyte-derived macrophages. The specific binding of $(A)$ human ${ }^{125} \mathrm{I}$ LDL, $(B)$ canine ${ }^{125} \mathrm{I}-$ apoE $\mathrm{HDL}_{\mathrm{c}}$, and $(C)$ canine ${ }^{125} \mathrm{I}-\beta$-VLDL are shown. Cells cultured in $35-\mathrm{mm}$ dishes for $5 \mathrm{~d}$ were incubated in DME containing $10 \%$ LPDS for $2 \mathrm{~d}$ before the experiment. Equilibrium binding assays were performed at $4^{\circ} \mathrm{C}$; nonspecific binding was defined as the amount of radioligand bound in the presence of a 100 -fold excess of the corresponding unlabeled lipoprotein. Each point is the average of duplicate determinations from a representative experiment. effective competitors. The cell-surface binding of ${ }^{125} \mathrm{I}-\beta$-VLDL by monocyte-macrophages at $4^{\circ} \mathrm{C}$ was specifically inhibited by unlabeled LDL, with $50 \%$ inhibition achieved at $15 \mu \mathrm{g}$ of LDL protein/ml (Fig. 2, top). The LDL were also effective competitors for the degradation of ${ }^{125} \mathrm{I}-\beta$-VLDL by the human monocyte-macrophages (Fig. 2, bottom). The LDL inhibited ${ }^{125} \mathrm{I}-\beta$ VLDL degradation by human monocyte-macrophages completely, with $50 \%$ inhibition achieved at $30 \mu \mathrm{g}$ of LDL protein $/ \mathrm{ml}$. Identical results were obtained when adherent monocytes were isolated and studied on the same day (data not shown).

The ability of LDL to inhibit the degradation of rabbit $\beta$-VLDL from cholesterol-fed hypercholesterolemic rabbits and human $\beta$-VLDL from a type III hyperlipidemic subject was also examined. As shown in Fig. 3, the degradation of rabbit, canine, and human ${ }^{125} \mathrm{I}-\beta$-VLDL by human monocytemacrophages was abolished by unlabeled human LDL. Thus, it appears that the same population of receptors binds, internalizes, and degrades both LDL and $\beta$-VLDL from three species.

Inhibition of $\beta-V L D L$ uptake by an antibody to the apoB, $E(L D L)$ receptor. To clarify further whether the uptake of $\beta$-VLDL by human monocyte-macrophages was mediated by the apoB,E(LDL) receptor, the cells were first preincubated with varying concentrations of a polyclonal antibody that blocks apoB,E(LDL) receptor activity (8). Cultured human fibroblasts were also included as a positive control. Human ${ }^{125} \mathrm{I}-\mathrm{LDL}$ or canine ${ }^{125} \mathrm{I}-\beta$-VLDL were then added, and their degradation in the presence or absence of the antibody was measured. Fig. 4 shows that the antibody inhibited degrada-

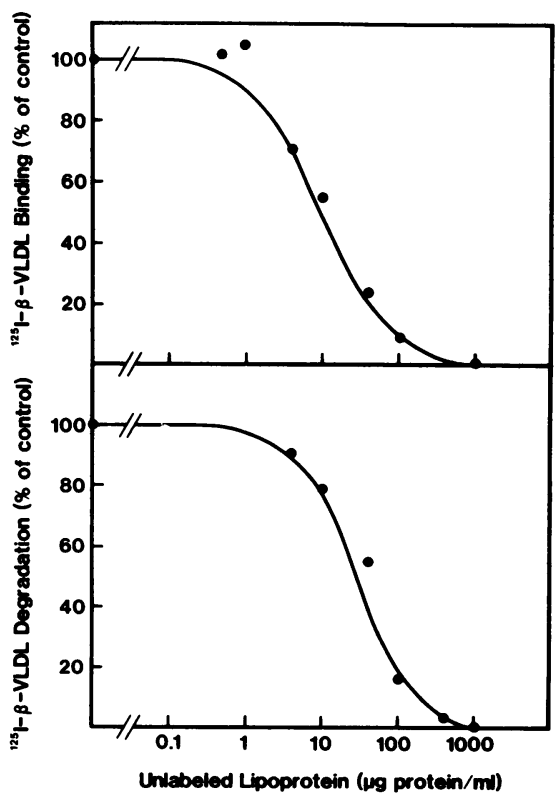

Figure 2. Ability of unlabeled human LDL to inhibit binding at $4^{\circ} \mathrm{C}$ (top) and proteolytic degradation at $37^{\circ} \mathrm{C}$ (bottom) of canine ${ }^{125} \mathrm{I}-\beta$ VLDL by human monocyte-derived macrophages. Monocyte-macrophages were incubated with either $1 \mu \mathrm{g} / \mathrm{ml}\left(4^{\circ} \mathrm{C}\right)$ or $5 \mu \mathrm{g} / \mathrm{ml}\left(37^{\circ} \mathrm{C}\right)$ of ${ }^{125} \mathrm{I}-\beta-\mathrm{VLDL}$ and the indicated concentrations of unlabeled LDL. The cell-surface binding of ${ }^{125} \mathrm{I}-\beta$-VLDL and the amount of ${ }^{125} \mathrm{I}-\beta$ VLDL degradation product were measured as described in Methods. The control (100\%) values were $43.6 \mathrm{ng}$ bound/ $\mathrm{mg}$ of cell protein and $0.66 \mu \mathrm{g}$ degraded $/ 6 \mathrm{~h} / \mathrm{mg}$ of cell protein. 


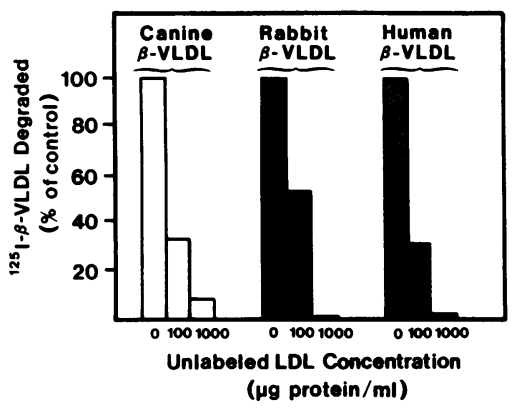

Figure 3. Ability of unlabeled human LDL to inhibit the degradation of canine, rabbit, and human ${ }^{125} \mathrm{I}-\beta$-VLDL by human monocyte-macrophages. Monocytemacrophages were incubated with $5 \mu \mathrm{g}$ of canine ${ }^{125} \mathrm{I}-\beta-\mathrm{VLDL} / \mathrm{ml}$, $15 \mu \mathrm{g}$ of rabbit ${ }^{125} \mathrm{I}-\beta$ $\mathrm{VLDL} / \mathrm{ml}$, or $5 \mu \mathrm{g}$ of human ${ }^{125} \mathrm{I}-\beta$-VLDL/ml and the indicated concentrations of unlabeled $\mathrm{LDL}$ at $37^{\circ} \mathrm{C}$. ${ }^{125} \mathrm{I}-\beta$ VLDL degradation was measured as described in Methods. Rates of degradation in the absence of LDL were $3.2,6.0$, and $3.8 \mu \mathrm{g} / \mathrm{mg}$ of cell protein, respectively.

tion of ${ }^{125} \mathrm{I}-\beta$-VLDL and ${ }^{125} \mathrm{I}-\mathrm{LDL}$ by monocyte-macrophages and human fibroblasts in a dose-dependent manner. Complete inhibition of binding was achieved at higher concentrations of IgG. These data support the conclusion that a single population of receptors, the apoB,E(LDL) receptors, mediates the binding and degradation of both $\beta$-VLDL and LDL.

Immunoblots of apoB,E(LDL) receptors. The same apoB,E(LDL) receptor antibody was used for immunoblots to characterize the apoB,E(LDL) receptors on human-monocyte macrophages, cultured human fibroblasts, and mouse peritoneal macrophages. As previously reported (8), and as illustrated in Fig. 5, the apoB,E(LDL) receptor on mouse peritoneal macrophages has an apparent molecular weight slightly lower than that of the human fibroblast receptor. Human monocyte-macrophages possessed a single immunoreactive band with an apparent molecular weight identical to that detected on human fibroblasts.

Regulation of lipoprotein receptors on human monocytemacrophages. Previous studies using mouse peritoneal macrophages demonstrated that the apoB, $\mathrm{E}(\mathrm{LDL})$ receptors on these cells were poorly down regulated by extracellular cholesterol compared with the receptors on human fibroblasts. To deter-

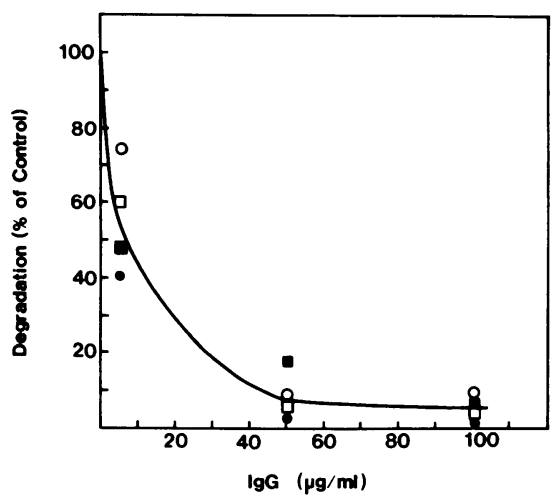

Figure 4. Inhibition of human ${ }^{125} \mathrm{I}-\mathrm{LDL}$ and canine ${ }^{125} \mathrm{I}-\beta-\mathrm{VLDL}$ degradation by an antibody to the bovine apoB,E(LDL) receptor. Human monocyte-macrophages $(\bullet, \square)$ or cultured fibroblasts $(0, \square)$ were preincubated with varying concentrations of $\operatorname{IgG}$ at $4^{\circ} \mathrm{C}$ for $2 \mathrm{~h}$.

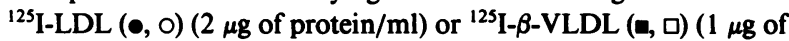
protein $/ \mathrm{ml}$ ) were then added to the cells and incubated for $16 \mathrm{~h}$ at $37^{\circ} \mathrm{C}$. The data are expressed as percentage of specific degradation of labeled lipoprotein in the absence of added antibodies.

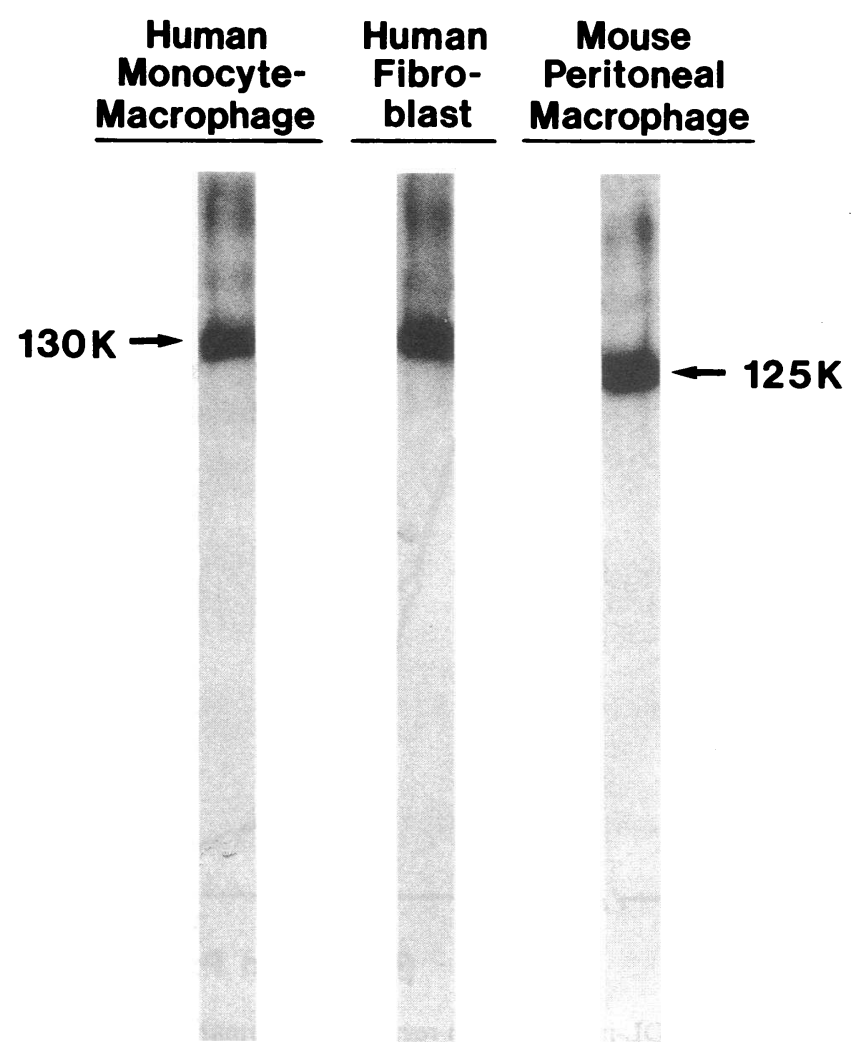

Figure 5. Immunoblots of apoB,E(LDL) receptors. Triton extracts of human monocyte-macrophages, human fibroblasts, or mouse peritoneal macrophages (100 $\mu \mathrm{g}$ of protein/lane) were electrophoresed on $7.5 \%$ polyacrylamide-SDS gels, transferred to nitrocellulose, and reacted with polyclonal antibodies to the apoB,E(LDL) receptor as described. Apparent molecular weights are indicated with arrows.

mine if this is also a property of apoB,E(LDL) receptors on human monocyte-macrophages, the binding of canine ${ }^{125} \mathrm{I}-\beta$ VLDL and human ${ }^{125}$ I-LDL to human monocyte-macrophages and human fibroblasts was examined after preincubation of the cells for $48 \mathrm{~h}$ with increasing concentrations of $\beta$-VLDL. After preincubation with $\beta$-VLDL, both human monocyte-macrophages and human fibroblasts demonstrated equivalent dose-dependent down regulation of ${ }^{125} \mathrm{I}-\beta$-VLDL and ${ }^{125}$ I-LDL binding (Fig. 6). Down regulation of the apoB,E(LDL) receptor content was also assessed by immunoblots using the polyclonal antibody made against bovine apoB,E(LDL) receptors. Densitometric scans of autoradiograms demonstrated that the apoB,E(LDL) receptor content was efficiently decreased by preincubation of the cells with $\beta$-VLDL (Fig. 6 A, inset).

Lipoprotein-induced cholesterol esterification and lipoprotein degradation by human monocyte-macrophages from homozygous familial hypercholesterolemic subjects. To confirm that the uptake of $\beta$-VLDL by human monocyte-macrophages was mediated by the apoB,E(LDL) receptor, cells from seven patients with the homozygous form of FH were investigated. Since homozygous $\mathrm{FH}$ subjects are genetically deficient in functional apoB,E(LDL) receptor activity, incubation of $\beta$ VLDL with monocyte-macrophages from these individuals would serve as a crucial test as to whether $\beta$-VLDL can be taken up by a process independent of the apoB,E(LDL) receptor. The clinical features and serum lipid levels of these sub- 


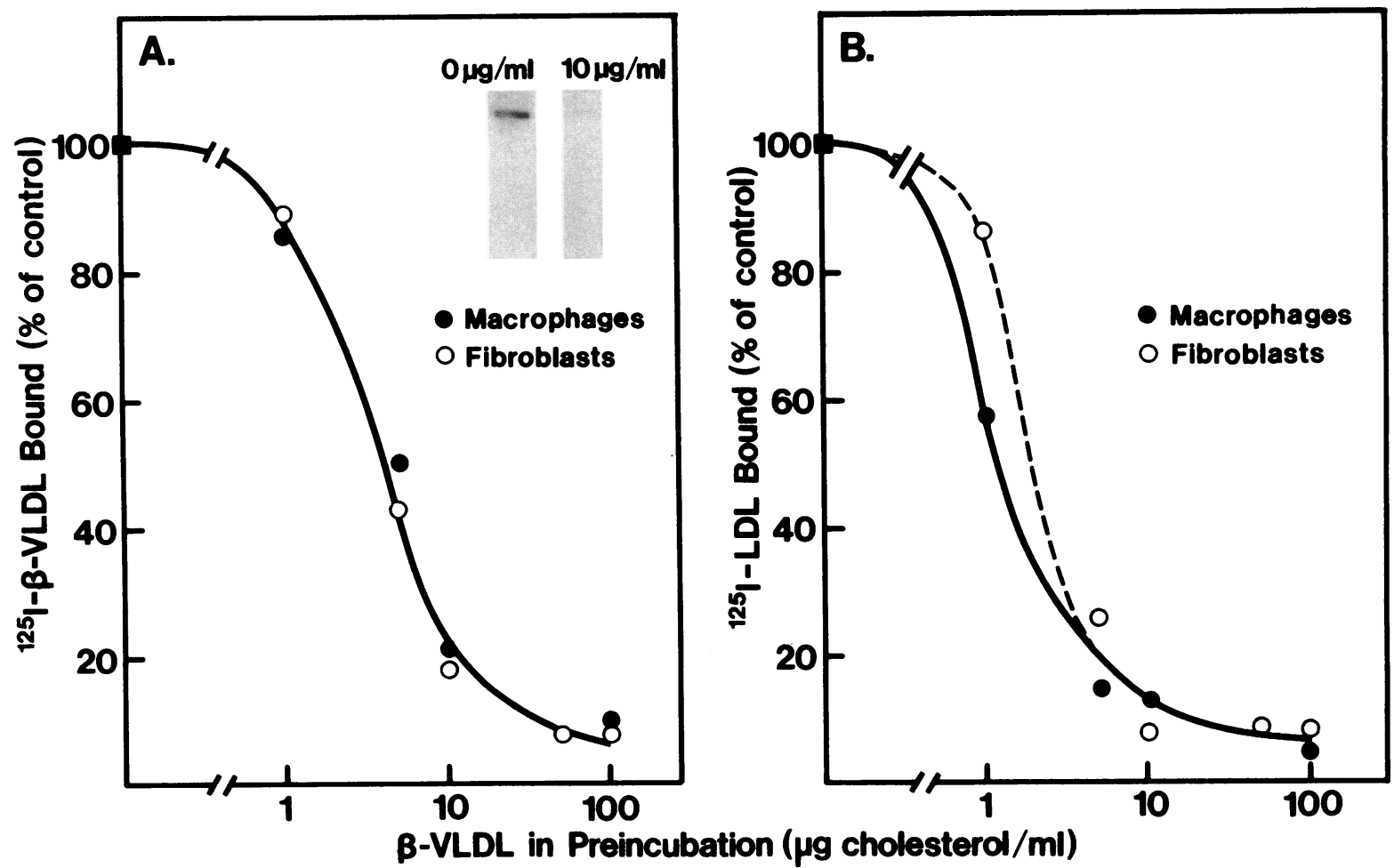

Figure 6. $\beta$-VLDL-induced down regulation of human ${ }^{125} \mathrm{I}-\mathrm{LDL}(A)$ and ${ }^{125} \mathrm{I}-\beta$-VLDL $(B)$ binding to monocyte-macrophages $(\bullet)$ or fibroblasts (O). Human monocyte-derived macrophages or human fibroblasts were incubated with the indicated concentrations of $\beta$-VLDL in DME containing 10\% lipoprotein-deficient serum (LPDS) for $48 \mathrm{~h}$ at $37^{\circ} \mathrm{C}$. The cells were then washed and further incubated in DME

jects (summarized in Table I) are typical of those with this genetic disorder.

As Fig. $7 A$ clearly demonstrates, neither human LDL, canine $\beta$-VLDL, rabbit $\beta$-VLDL, nor human type III $\beta$-VLDL containing $10 \% \mathrm{LPDS}$ at $37^{\circ} \mathrm{C}$ for $1 \mathrm{~h}$ to allow for internalization of the remaining surface-bound $\beta$-VLDL. ${ }^{125} \mathrm{I}-\mathrm{LDL}$ or ${ }^{125} \mathrm{I}-\beta$-VLDL binding was then assessed at $4^{\circ} \mathrm{C}$. Each point represents the average values of triplicate determinations. The inset in $\mathrm{A}$ is an immunoblot of apoB,E(LDL) receptors from monocyte-macrophages incubated in the absence or presence of $10 \mu \mathrm{g}$ of cholesterol $/ \mathrm{ml}$.

were degraded by the FH cells. In addition, in comparison with normal monocyte-macrophages, these lipoproteins induced only minimal amounts of cholesteryl $\left[{ }^{14} \mathrm{C}\right]$ oleate in the $\mathrm{FH}$ monocyte-macrophages (Fig. 7 B). AcAc LDL were used as a

Table I. Clinical Features and Serum Lipid Levels of Familial Hypercholesterolemia Subjects

\begin{tabular}{|c|c|c|c|c|c|}
\hline Subject & Age, sex & Plasma cholesterol & Plasma triglycerides & Clinical characteristics & LDL receptor \\
\hline & & $m g / d l$ & $m g / d l$ & & \\
\hline F.L.* & $19 \mathrm{~F}$ & 720 & 110 & Xanthomas, corneal arcus & Negative LDL binding \\
\hline M.K. ${ }^{\ddagger}$ & $6 \mathrm{M}$ & 1170 & 178 & Xanthomas & $25 \%$ of normal LDL binding \\
\hline G.R.8 & $\mathrm{ND}^{\prime \prime} \mathbf{M}$ & ND & ND & Xanthomas, aortic stenosis & Receptor defective \\
\hline S.J.' & $9 \mathrm{~F}$ & 1070 & 238 & Xanthomas, coronary artery disease & $<5 \%$ of normal LDL binding \\
\hline G.E.**\#\# & $5 \mathrm{~F}$ & 791 & 174 & Xanthomas & Negative binding, no receptor protein \\
\hline R.H. & $9 \mathbf{M}$ & 770 & 101 & Xanthomas, aortic stenosis & $1 \%$ of normal LDL binding \\
\hline 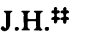 & $6 \mathrm{~F}$ & 1041 & 153 & Xanthomas, aortic stenosis & $1 \%$ of normal LDL binding \\
\hline R.M. ${ }^{\ddagger \neq 88}$ & ND F & 675 & 275 & Xanthomas & $25 \%$ of normal LDL binding \\
\hline
\end{tabular}

\footnotetext{
* This is a patient of Dr. Gerd Assmann, Munster, West Germany. ‡ This is a patient of Dr. Mary J. Malloy, University of California, San Francisco, CA. The patient is on triple drug treatment (colestipol, nicotinic acid, mevinolin). At the time of the study, the plasma cholesterol and triglyceride levels were 372 and $99 \mathrm{mg} / \mathrm{dl}$, respectively. ${ }^{8}$ Dr. Tom Parker at the Rogosin Institute of Medical Research and Health Care, New York, NY, sent the blood from this patient. "No data. 'This patient had a liver and heart transplant and is being treated with mevinolin. At the time of the study, her plasma cholesterol and triglyceride levels were 171 and $121 \mathrm{mg} / \mathrm{dl}$, respectively. This patient has one null allele and one LDL receptor allele that produces a nonprocessed receptor (30). ** No LDL receptor antibody could be detected with bovine LDL receptor antibody. DNA studies indicated a Lebanese allele (31). \# These are patients of Dr. Ricardo Uauy, Dallas, TX. At the time of the study, this patient had been on a low-fat, low-cholesterol diet and the plasma cholesterol and triglyceride levels were 327 and $95 \mathrm{mg} / \mathrm{dl}$, respectively. This patient is probably a FH heterozygote.
} 


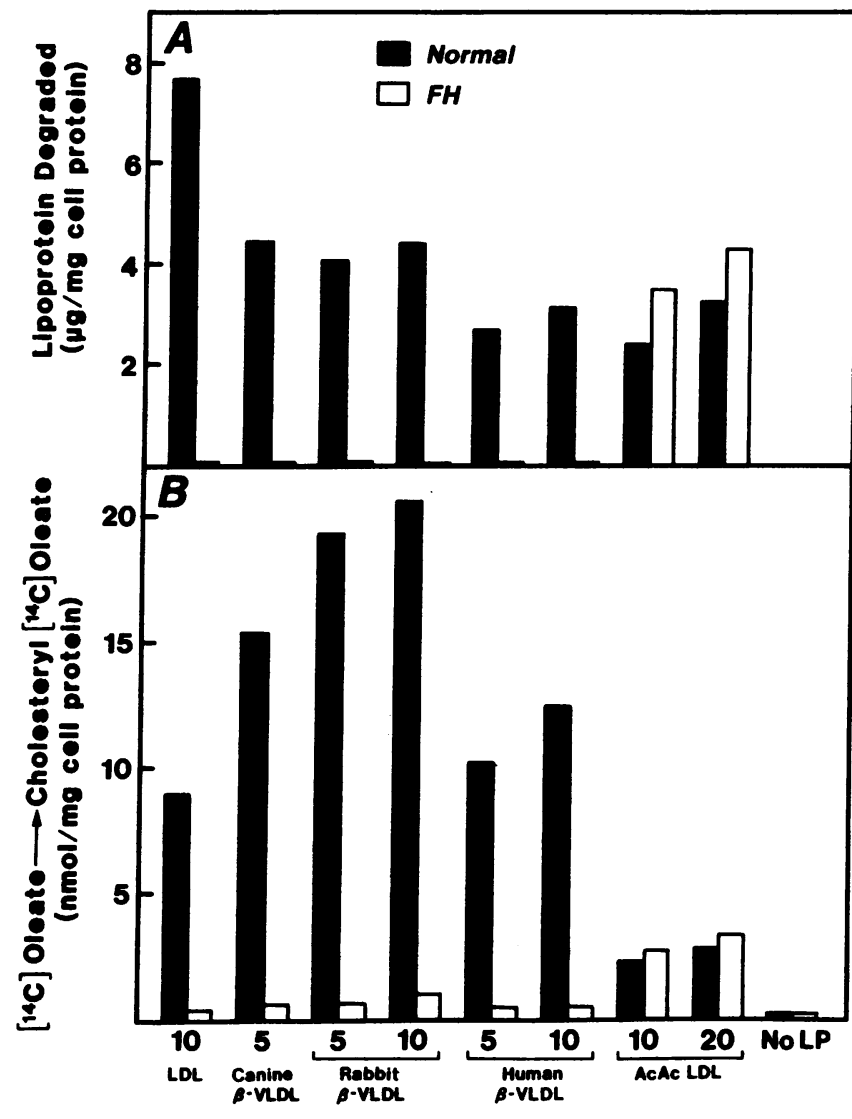

Figure 7. Degradation of ${ }^{125} \mathrm{I}$-labeled lipoproteins $(A)$ and lipoprotein-induced stimulation of cholesterol esterification $(B)$ in monocyte-macrophages of normal and FH subjects. Monocyte-macrophages were cultured in 22-mm dishes for $4 \mathrm{~d}$ in DME containing $20 \%$ human $\mathrm{AB}^{+}$serum and then for $2 \mathrm{~d}$ in DME containing $10 \%$ LPDS. Cells were incubated with ${ }^{125} \mathrm{I}$-labeled lipoproteins $\pm\left[{ }^{14} \mathrm{C}\right]-$ oleate at $37^{\circ} \mathrm{C}$ for $16 \mathrm{~h}$. Degradation of ${ }^{125} \mathrm{I}$-labeled lipoproteins and synthesis of cholesteryl $\left[{ }^{14} \mathrm{C}\right]$ oleate were measured as described in Methods. Concentrations (micrograms of protein/milliliter) of each lipoprotein are indicated beneath the lower panel. Degradation is corrected for nonspecific degradation, with the exception of AcAc LDL. Each value is the average of duplicate determinations from a representative experiment. No LP, no lipoprotein added. control since the internalization of these lipoproteins is mediated by the acetyl-LDL, or scavenger, receptor which is normally expressed in both normal and FH cells (32). Similar amounts of AcAc LDL were degraded in both cell types (Fig. 7 $A)$. In addition, cholesteryl ester formation induced by AcAc LDL was equivalent in normal and FH cells (Fig. 7 B). The cells for the experiment shown in Fig. 7 were derived from homozygote S. J. Bilheimer et al. (30) have shown that S.J. has one LDL receptor allele that produces no LDL receptor (null allele); the other allele produces nonprocessed receptors. Results from all seven subjects are summarized in Tables II and III. In all cases, FH cells demonstrated little or no uptake and degradation of ${ }^{125} \mathrm{I}-\mathrm{LDL}$, as expected. The relative inability of these cells to degrade $\beta$-VLDL and to esterify the internalized cholesterol parallel their relative inability to metabolize ${ }^{125} \mathrm{I}$ LDL, indicating that no separate pathway exists in these cells for the receptor-mediated uptake of $\beta$-VLDL. Monocyte-macrophages from the single heterozygous FH subject (R.M.) showed an intermediate level of uptake of both $\beta$-VLDL and LDL (Tables II and III), i.e., the uptake levels were between those for the homozygous FH subjects and those for normal subjects (data not shown).

\section{Discussion}

Previously, Van Lenten et al. (11) described the uptake and degradation of rabbit $\beta$-VLDL by human monocyte-macrophages. These features were noted: $(a)$ The process was dependent on $\mathrm{Ca}^{2+}$, (b) the uptake of LDL and $\beta$-VLDL was highest soon after the monocytes were cultured and tended to decline with time in culture, $(c)$ the uptake of both lipoproteins was mediated by a specific high-affinity process, $(d)$ the process was up regulated by lipoprotein-deficient serum in the medium and down regulated by preincubation of the cells with sterol in the medium, and $(e)$ the receptor activity recognized lipoproteins (at least in part) by their apoE content (11). There was, however, one key difference between the degradation of LDL and $\beta$-VLDL by the human monocytes. In monocytes from a homozygous FH patient, the amount of ${ }^{125}$ I-labeled rabbit $\beta$-VLDL that was degraded was only slightly reduced compared with that of normal human monocytes (11). In contrast, the amount of ${ }^{125} \mathrm{I}$-labeled human LDL degraded was

Table II. Degradation of ${ }^{125}$ I-Labeled Lipoproteins by Human Monocyte-Macrophages from Familial Hypercholesterolemia Subjects*

\begin{tabular}{|c|c|c|c|c|c|c|c|c|c|c|}
\hline & \multicolumn{2}{|c|}{ Human LDL } & \multicolumn{2}{|c|}{ Canine $\beta$-VLDL } & \multicolumn{2}{|c|}{ Rabbit $\beta$-VLDL } & \multicolumn{2}{|c|}{ Human $\beta$-VLDL } & \multicolumn{2}{|c|}{ Human AcAc LDL } \\
\hline & $\mu g / m g$ & $\%$ & $\mu g / m g$ & $\%$ & $\mu g / m g$ & $\%$ & $\mu g / m g$ & $\%$ & $\mu g / m g$ & $\%$ \\
\hline F.L. & $0^{8}$ & 0 & 0.005 & 1.6 & \multicolumn{2}{|c|}{ ND" } & \multicolumn{2}{|c|}{ ND } & \multicolumn{2}{|c|}{ ND } \\
\hline M.K. & 0.21 & 2.8 & 0.16 & 15.6 & \multirow{2}{*}{\multicolumn{2}{|c|}{ ND }} & \multicolumn{2}{|c|}{ ND } & \multirow{2}{*}{\multicolumn{2}{|c|}{ ND }} \\
\hline & 0.32 & 4.9 & 0.14 & 12.5 & & & & & & \\
\hline G.R. & 1.55 & 9.2 & 0.30 & 6.5 & 0.53 & 14 & \multicolumn{2}{|c|}{ ND } & \multicolumn{2}{|c|}{ ND } \\
\hline \multirow[t]{2}{*}{ S.J. } & 0.12 & 0.4 & 0.01 & 0.2 & 0.04 & 1 & 0.01 & 0.1 & 3.49 & 144 \\
\hline & & & & & 0 & 0 & 0 & 0 & 4.29 & 133 \\
\hline G.E. & 0.04 & 1.4 & \multicolumn{2}{|c|}{ ND } & 0.08 & 3.9 & 0.02 & 1.1 & 2.60 & 481 \\
\hline R.H. & 0.06 & 1.7 & 0.03 & 2.0 & 0.24 & 8.6 & 0.02 & 8.6 & 1.05 & 198 \\
\hline J.H. & 0.02 & 0.4 & \multicolumn{2}{|c|}{ ND } & 0.05 & 1.5 & 0 & 0 & 0.71 & 142 \\
\hline R.M.' & 2.69 & 72 & 2.13 & - & 3.27 & 62 & 1.90 & 61 & 6.12 & 72 \\
\hline
\end{tabular}

* Cells were cultured as in Fig. 7 and incubated for $18 \mathrm{~h}$ with ${ }^{125} \mathrm{I}$-labeled lipoproteins at $37^{\circ} \mathrm{C}$, and degradation was determined as described in Methods. ${ }^{\ddagger}$ AcAc LDL, acetoacetylated LDL. 'All data are presented as a percentage of the specific (LDL, $\beta$-VLDL) or total (AcAc LDL) degradation of a parallel normal control and as $\mu \mathrm{g}$ of lipoprotein degraded/mg of cell protein. "ND. "FH heterozygote. 
Table III. Lipoprotein-induced Cholesterol Esterification by Human Monocyte-Macrophages

from Familial Hypercholesterolemia Subjects*

\begin{tabular}{|c|c|c|c|c|c|c|c|c|c|c|}
\hline & \multicolumn{2}{|c|}{ Human LDL } & \multicolumn{2}{|c|}{ Canine $\beta$-VLDL } & \multicolumn{2}{|c|}{ Rabbit $\beta$-VLDL } & \multicolumn{2}{|c|}{ Human $\beta$-VLDL } & \multicolumn{2}{|c|}{ Human AcAc LDL } \\
\hline & $n \mathrm{~mol} / \mathrm{mg}$ & $\%$ & nmol/mg & $\%$ & nmol/mg & $\%$ & nmol/mg & $\%$ & $\mathrm{nmol} / \mathrm{mg}$ & $\%$ \\
\hline F.L. & $0.72^{\S}$ & 7.6 & 3.43 & 7.6 & \multicolumn{2}{|c|}{ ND" } & \multicolumn{2}{|c|}{ ND } & \multicolumn{2}{|c|}{ ND } \\
\hline M.K. & 0 & 0 & 0.4 & 1.8 & \multirow{2}{*}{\multicolumn{2}{|c|}{ ND }} & \multicolumn{2}{|c|}{ ND } & \multicolumn{2}{|c|}{ ND } \\
\hline & & & 0.1 & 0.1 & & & & & & \\
\hline G.R. & 2.30 & 2.0 & 4.63 & 6.0 & 5.57 & 7.5 & \multicolumn{2}{|c|}{ ND } & \multicolumn{2}{|c|}{ ND } \\
\hline \multirow[t]{2}{*}{ S.J. } & 0.2 & 2.3 & 0.4 & 3.9 & 0.5 & 4.9 & 0.3 & 4.9 & 2.5 & 119 \\
\hline & & & & & 0.8 & 3.6 & 0.3 & 4.0 & 3.1 & 115 \\
\hline G.E. & 0 & 0 & & & 0 & 0 & 0 & 0 & \multicolumn{2}{|c|}{ ND } \\
\hline R.H. & 0 & 0 & 0 & 0 & 0.2 & 1.2 & 0 & 0 & 0.7 & 113 \\
\hline J.H. & 0 & 0 & \multicolumn{2}{|c|}{ ND } & 0.2 & 1.6 & 0 & 0 & 0.7 & 128 \\
\hline R.M. & 2.0 & 5.6 & 11.1 & - & 18.5 & 75 & 6.8 & 59 & 10.4 & 158 \\
\hline
\end{tabular}

* Cells were cultured as in Fig. 7 and incubated for $18 \mathrm{~h}$ with $\left[{ }^{14} \mathrm{C}\right]$ oleate and various lipoproteins at $37^{\circ} \mathrm{C}$, and the production of cholesteryl $\left[{ }^{14} \mathrm{C}\right]$ oleate was measured as described in Methods. ${ }^{\ddagger}$ AcAc LDL, acetoacetylated LDL. ${ }^{\S}$ Data are presented as a percentage of the lipoprotein-induced cholesterol esterification of a parallel normal control and as nanomoles of cholesteryl esters synthesized/milligram of cell protein. "ND.

greatly reduced in these cells. These results were interpreted as confirmation of the suggestion by Goldstein et al. (5) that the receptor recognizing $\beta$-VLDL was a genetically distinct receptor similar to the postulated " $\beta$-VLDL receptor" on the cell surface of mouse peritoneal macrophages.

However, our studies (8) demonstrated that mouse macrophages contain an unusual apoB,E(LDL) receptor instead of a genetically distinct $\beta$-VLDL receptor. Therefore, the present study was undertaken to clarify potential differences between these particular mouse and human cells with respect to the presence or absence of the $\beta$-VLDL receptor. The data obtained in our study demonstrate that human macrophages derived from circulating monocytes bind and internalize $\beta$ VLDL by an apoB,E(LDL) receptor pathway that appears to be identical to the classic apoB,E(LDL) receptor described on cultured human fibroblasts. The following evidence indicates that the internalization of $\beta$-VLDL by human monocyte-macrophages is mediated by the apoB,E(LDL) receptor: $(a)$ binding and degradation of $\beta$-VLDL can be completely inhibited by excess unlabeled LDL or by preincubation with an antibody that blocks apoB,E(LDL) receptor activity; $(b)$ the apoB,E(LDL) receptor antibody that abolishes $\beta$-VLDL uptake by human macrophages recognizes a single band (the apoB,E(LDL) receptor) on immunoblots of extracts of human macrophages; $(c)$ the affinities of the receptors on human monocyte-macrophages for $\beta$-VLDL, apo-E HDL $\mathrm{HL}_{\mathrm{c}}$, and LDL are similar, if not identical, to the affinities of the classic apoB,E(LDL) receptors on human fibroblasts for these same lipoproteins; $(d)$ the expression of the apoB,E(LDL) receptor was down regulated equivalently in human fibroblasts and human monocyte-macrophages by preincubation of the cells with $\beta$-VLDL; and ( $e$ ) macrophages derived from blood monocytes from seven patients with homozygous $\mathrm{FH}$ degraded very little (if any) $\beta$-VLDL.

These results agree with previous studies that demonstrated that mouse peritoneal macrophages also internalize $\beta$ VLDL through an apoB,E(LDL) receptor $(8,9)$. However, in contrast to the apoB,E(LDL) receptor on human monocytemacrophages, the mouse apoB,E(LDL) receptors differ from the classic apoB,E(LDL) receptors in apparent molecular size
(Fig. 5), binding affinity for $\operatorname{LDL}(32.9 \mu \mathrm{g} / \mathrm{ml}$ for mouse peritoneal macrophages vs. $1.65 \mu \mathrm{g} / \mathrm{ml}$ for human monocyte-macrophages), and relative sensitivity to down regulation when compared with human fibroblasts (8).

Our conclusion that the apoB,E(LDL) receptor on human monocyte-macrophages is responsible for the uptake of $\beta$ VLDL differs from that of several previous studies. Although the reasons for these differences are not fully understood, there are several plausible explanations for the differences. The evidence for a distinct $\beta$-VLDL receptor was based primarily on two results: a 25 -fold excess of LDL did not completely inhibit ${ }^{125} \mathrm{I}-\beta$-VLDL degradation, and the monocyte-macrophages from a single individual with homozygous $\mathrm{FH}$ appeared to degrade $\beta$-VLDL at levels approximating normal controls, whereas LDL degradation was minimal (11). We now know that because $\beta$-VLDL bind with much higher affinity to the apoB,E(LDL) receptor than LDL, a 25 -fold excess of LDL would not completely inhibit the ${ }^{125} \mathrm{I}-\beta$-VLDL degradation. Therefore, the partial inhibition of $\beta$-VLDL degradation at a 25 -fold excess of LDL reported previously and confirmed in this study can be explained as a difference in the affinities of the two lipoprotein ligands (see reference 33 for a discussion of this general phenomenon).

Other studies demonstrated that $\beta$-VLDL were degraded by macrophages from FH homozygotes, whereas the present results did not. The difference may be accounted for by a recent study by Hobbs et al. (34). They discovered that apoB,E(LDL) receptors from one $\mathrm{FH}$ homozygous patient bound almost no human LDL, but interacted with rabbit $\beta$ VLDL with the high affinity typical of the normal apoB,E(LDL) receptor. In addition, Davis et al. have also demonstrated that deletion of the epidermal growth factor precursor region of the apoB,E(LDL) receptor markedly reduces LDL binding but not $\beta$-VLDL binding (35). It is possible that the FH subjects studied by Van Lenten et al. $(11,36)$ and Wang-Iverson et al. (37) had similar mutations. Differences in lipoproteins or experimental conditions may also account for the degradation of $\beta$-VLDL in FH monocytes in the previous studies.

The $\beta$-VLDL are abnormal lipoproteins present in large 
amounts in animals fed a high-cholesterol diet or in patients with type III hyperlipoproteinemia (1-3). These lipoproteins are not normally found in the plasma from fasted, normal individuals. However, VLDL and chylomicron remnants that are found in normal individuals resemble the $\beta$-VLDL (2). Van Lenten et al. (36) have demonstrated that chylomicron remnants enter human monocyte-macrophages by the same pathway as $\beta$-VLDL. In view of results from the present studies, chylomicron remnants would be expected to be taken up by the apoB,E(LDL) receptors on human monocyte-macrophages. Indeed, Floren and Chait (38) have shown that chylomicron remnants are internalized by human monocyte-macrophages through the classic apoB,E(LDL) receptor pathway equivalent to that in cultured human fibroblasts.

The results presented here and in previous studies $(8,9)$ suggest that the propensity of monocytes to become foam cells when incubated with cholesterol-enriched lipoproteins, such as $\beta$-VLDL, is not a result of the presence of a unique population of receptors for these lipoproteins. The overaccumulation of cholesteryl esters by the monocyte-macrophages, despite a well-regulated apoB,E(LDL) receptor pathway, argues that the formation of foam cells by human monocyte-macrophages results from other properties of these cells. For example, Tabas et al. $(10,39)$ showed that mouse peritoneal macrophages did not esterify appreciable amounts of LDL-derived cholesterol even though these lipoproteins were apparently internalized and degraded by the cells. Since $\beta$-VLDL could induce significant cholesteryl ester accumulation in mouse peritoneal macrophages, the inference is that LDL-derived cholesterol is processed differently than $\beta$-VLDL-derived cholesterol. Likewise, it is possible that $\beta$-VLDL-derived cholesterol is handled differently in human monocyte-macrophages compared with human fibroblasts. Foam cell formation could arise in part from non-receptor-mediated endocytotic uptake of cholesterol-enriched lipoproteins in the prolonged presence of concentrations of these lipoproteins far above the saturating concentration for the receptors. Alternatively, the efflux of cholesterol from a cholesteryl ester-loaded monocyte-macrophage may be impaired because of the paucity of cholesterol acceptors in hypercholesterolemic plasma (1). In addition, the regulation of intracellular cholesterol levels and intracellular sites of cholesterol storage may be important, e.g., the availability of cholesterol for efflux from monocyte-macrophages may differ from that observed in other cells. In fact, Pitas et al. (40) have demonstrated that cholesterol in macrophage foam cells in rabbit atherosclerotic lesions is resistant to mobilization by cholesterol acceptors in the medium. A combination of properties unique to these cells may account for the formation of foam cells in response to chylomicron and VLDL remnants.

\section{Acknowledgments}

We thank Kerry Humphrey and Debbie Coller for manuscript preparation, Kay Arnold and Maureen Balestra for technical assistance, James X. Warger for graphics, and Al Averbach and Sally Gullatt Seehafer for editorial assistance. We also thank Dr. Gerd Assmann and Dr. Tom Parker for blood from FH homozygotes.

\section{References}

1. Brown, M. S., and J. L. Goldstein. 1983. Lipoprotein metabolism in the macrophage: implications for cholesterol deposition in atherosclerosis. Annu. Rev. Biochem. 52:223-261.
2. Mahley, R. W., T. L. Innerarity, S. C. Rall, Jr., and K. H. Weisgraber. 1985. Lipoproteins of special significance in atherosclerosis: insights provided by studies of type III hyperlipoproteinemia. Ann. NY Acad. Sci. 454:209-221.

3. Mahley, R. W. 1983. Development of accelerated atherosclerosis. Concepts derived from cell biology and animal model studies. Arch. Pathol. Lab. Med. 107:393-398.

4. Mahley, R. W. 1982. Atherogenic hyperlipoproteinemia. The cellular and molecular biology of plasma lipoproteins altered by dietary fat and cholesterol. Med. Clin. N. Am. 66:375-402.

5. Goldstein, J. L., Y. K. Ho, M. S. Brown, T. L. Innerarity, and R. W. Mahley. 1980. Cholesteryl ester accumulation in macrophages resulting from receptor-mediated uptake and degradation of hypercholesterolemic canine $\beta$-very low density lipoproteins. J. Biol. Chem. 255:1839-1848.

6. Mahley, R. W., T. L. Innerarity, M. S. Brown, Y. K. Ho, and J. L. Goldstein. 1980. Cholesteryl ester synthesis in macrophages: stimulation by $\beta$-very low density lipoproteins from cholesterol-fed animals of several species. J. Lipid Res. 21:970-980.

7. Brown, M. S., and J. L. Goldstein. 1986. A receptor-mediated pathway for cholesterol homeostasis. Science (Wash. DC). 232:34-47.

8. Koo, C., M. E. Wernette-Hammond, and T. L. Innerarity. 1986. Uptake of canine $\beta$-very low density lipoproteins by mouse peritoneal macrophages is mediated by a low density lipoprotein receptor. J. Biol. Chem. 261:11194-11201.

9. Ellsworth, J. L., F. B. Kraemer, and A. D. Cooper. 1987. Transport of $\beta$-very low density lipoproteins and chylomicron remnants by macrophages is mediated by the low density lipoprotein receptor pathway. J. Biol. Chem. 262:2316-2325.

10. Tabas, I., G. C. Boykow, and A. R. Tall. 1987. Foam cellforming $\mathrm{J774}$ macrophages have markedly elevated acyl coenzyme A:cholesterol acyl transferase activity compared with mouse peritoneal macrophages in the presence of LDL despite similar LDL receptor activity. J. Clin. Invest. 79:418-426.

11. Van Lenten, B. J., A. M. Fogelman, M. M. Hokom, L. Benson, M. E. Haberland, and P. A. Edwards. 1983. Regulation of the uptake and degradation of $\beta$-very low density lipoprotein in human monocyte macrophages. J. Biol. Chem. 258:5151-5157.

12. Bøyum, A. 1976. Isolation of lymphocytes, granulocytes and macrophages. Scand. J. Immunol. 5(Suppl. 5):9-15.

13. Innerarity, T. L., T. P. Bersot, K. S. Arnold, K. H. Weisgraber, P. A. Davis, T. M. Forte, and R. W. Mahley. 1984. Receptor binding activity of high-density lipoproteins containing apoprotein $E$ from abetalipoproteinemic and normal neonate plasma. Metab. Clin. Exp. 33:186-195.

14. Weisgraber, K. H., T. L. Innerarity, and R. W. Mahley. 1978. Role of the lysine residues of plasma lipoproteins in high affinity binding to cell surface receptors on human fibroblasts. J. Biol. Chem. 253:9053-9062.

15. Mahley, R. W., T. L. Innerarity, K. H. Weisgraber, and D. L. Fry. 1977. Canine hyperlipoproteinemia and atherosclerosis: accumulation of lipid by aortic medial cells in vivo and in vitro. Am. J. Pathol. 87:205-226.

16. Bersot, T. P., T. L. Innerarity, R. W. Mahley, and R. J. Havel. 1983. Cholesteryl ester accumulation in mouse peritoneal macrophages induced by $\beta$-migrating very low density lipoproteins from patients with atypical dysbetalipoproteinemia. J. Clin. Invest. 72:1024-1033.

17. Lowry, O. H., N. J. Rosebrough, A. L. Farr, and R. J. Randall. 1951. Protein measurement with the Folin phenol reagent. J. Biol. Chem. 193:265-275.

18. Bilheimer, D. W., S. Eisenberg, and R. I. Levy. 1972. The metabolism of very low density lipoproteins. I. Preliminary in vitro and in vivo observations. Biochim. Biophys. Acta. 260:212-221.

19. Bolton, A. E., and W. M. Hunter. 1973. The labelling of proteins to high specific radioactivities by conjugation to ${ }^{125}$ I-containing acylating agent. Application to the radioimmunoassay. Biochem. J. 133:529-539. 
20. Ey, P. L., S. J. Prowse, and C. R. Jenkin. 1978. Isolation of pure IgG, $\operatorname{IgG}_{2 a}$, and $\operatorname{IgG}_{2 b}$ immunoglobulins from mouse serum using protein A-Sepharose. Immunochemistry. 15:429-436.

21. Innerarity, T. L., R. E. Pitas, and R. W. Mahley. 1980. Receptor binding of cholesterol-induced high-density lipoproteins containing predominantly apoprotein $\mathrm{E}$ to cultured fibroblasts with mutations at the low-density lipoprotein receptor locus. Biochemistry. 19:43594365.

22. Scatchard, G. 1949. The attractions of proteins for small molecules and ions. Ann. NY Acad. Sci. 51:660-672.

23. Innerarity, T. L., R. E. Pitas, and R. W. Mahley. 1986. Lipoprotein-receptor interactions. Methods Enzymol. 129:542-566.

24. Goldstein, J. L., S. K. Basu, and M. S. Brown. 1983. Receptormediated endocytosis of low density lipoproteins in cultured cells. Methods Enzymol. 98:241-260.

25. Goldstein, J. L., and M. S. Brown. 1974. Binding and degradation of low density lipoproteins by cultured human fibroblasts. Comparison of cells from a normal subject and from a patient with homozygous familial hypercholesterolemia. J. Biol. Chem. 249:5153-5162.

26. Russell, D. W., W. J. Schneider, T. Yamamoto, K. L. Luskey, M. S. Brown, and J. L. Goldstein. 1984. Domain map of the LDL receptor: sequence homology with the epidermal growth factor precursor. Cell. 37:577-585.

27. Beisiegel, U., T. Kita, R. G. W. Anderson, W. J. Schneider, M. S. Brown, and J. L. Goldstein. 1981. Immunologic cross-reactivity of the low density lipoprotein receptor from bovine adrenal cortex, human fibroblasts, canine liver and adrenal gland, and rat liver. J. Biol. Chem. 256:4071-4078.

28. Towbin, H., T. Staehelin, and J. Gordon. 1979. Electrophoretic transfer of proteins from polyacrylamide gels to nitrocellulose sheets: procedure and some applications. Proc. Natl. Acad. Sci. USA. 76:4350-4354.

29. Pitas, R. E., T. L. Innerarity, K. S. Arnold, and R. W. Mahley. 1979. Rate and equilibrium constants for binding of apo-E $\mathrm{HDL}_{\mathrm{c}}(\mathrm{a}$ cholesterol-induced lipoprotein) and low density lipoproteins to human fibroblasts: evidence for multiple receptor binding of apo-E HDL $_{c}$. Proc. Natl. Acad. Sci. USA. 76:2311-2315.

30. Bilheimer, D. W., J. L. Goldstein, S. M. Grundy, T. E. Starzl, and M. S. Brown. 1984. Liver transplantation to provide low-densitylipoprotein receptors and lower plasma cholesterol in a child with homozygous familial hypercholesterolemia. N. Engl. J. Med. 311:1658-1664.
31. Lehrman, M. A., W. J. Schneider, M. S. Brown, C. G. Davis, A. Elhammer, D. W. Russell, and J. L. Goldstein. 1987. The Lebanese allele at the low density lipoprotein receptor locus. Nonsense mutation produces truncated receptor that is retained in endoplasmic reticulum. J. Biol. Chem. 262:401-410.

32. Shechter, I., A. M. Fogelman, M. E. Haberland, J. Seager, M. Hokom, and P. A. Edwards. 1981. The metabolism of native and malondialdehyde-altered low density lipoproteins by human monocyte-macrophages. J. Lipid Res. 22:63-71.

33. Jacobs, S., K.-J. Chang, and P. Cuatrecasas. 1975. Estimation of hormone receptor affinity by competitive displacement of labeled ligand: effect of concentration of receptor and of labeled ligand. Biochem. Biophys. Res. Commun. 66:687-692.

34. Hobbs, H. H., M. S. Brown, J. L. Goldstein, and D. W. Russell. 1986. Deletion of exon encoding cysteine-rich repeat of low density lipoprotein receptor alters its binding specificity in a subject with familial hypercholesterolemia. J. Biol. Chem. 261:13114-13120.

35. Davis, C. G., J. L. Goldstein, T. C. Südhof, R. G. W. Anderson, D. W. Russell, and M. S. Brown. 1987. Acid-dependent ligand dissociation and recycling of LDL receptor mediated by growth factor homology region. Nature (Lond.). 326:760-765.

36. Van Lenten, B. J., A. M. Fogelman, R. L. Jackson, S. Shapiro, M. E. Haberland, and P. A. Edwards. 1985. Receptor-mediated uptake of remnant lipoproteins by cholesterol-loaded human monocyte-macrophages. J. Biol. Chem. 260:8783-8788.

37. Wang-Iverson, P., H. N. Ginsberg, L. A. Peteanu, N. A. Le, and W. V. Brown. 1985. Apo-E-mediated uptake and degradation of normal very low density lipoproteins by human monocyte/macrophages: A saturable pathway distinct from the LDL receptor. Biochem. Biophys. Res. Commun. 126:578-586.

38. Floren, C.-H., and A. Chait. 1981. Uptake of chylomicron remnants by the native LDL receptor in human monocyte-derived macrophages. Biochim. Biophys. Acta. 665:608-611.

39. Tabas, I., D. A. Weiland, and A. R. Tall. 1985. Unmodified low density lipoprotein causes cholesteryl ester accumulation in $\mathrm{J} 774$ macrophages. Proc. Natl. Acad. Sci. USA. 82:416-420.

40. Pitas, R. E., T. L. Innerarity, and R. W. Mahley. 1983. Foam cells in explants of atherosclerotic rabbit aortas have receptors for $\beta$-very low density lipoproteins and modified low density lipoproteins. Arteriosclerosis. 3:2-12. 